\title{
Thickness-dependence of the translaminar fracture toughness: experimental study using thin-ply composites
}

\author{
R. F. Teixeira ${ }^{\mathrm{a}, *}$, S. T. Pinho ${ }^{\mathrm{a}}$, P. Robinson ${ }^{\mathrm{a}}$ \\ ${ }^{a}$ Imperial College London, South Kensington, SW7 2AZ, London
}

\begin{abstract}
The concept of translaminar fracture toughness of $0^{\circ}$ plies has enabled the development of a considerable number of ply-level numerical models for structural failure of laminated composites. Using thin-ply pre-pregs, this paper demonstrates that this translaminar toughness is not an absolute, but rather in-situ, property and depends strongly on the $0^{\circ}$ ply-block thickness, even in situations where delamination and diffuse damage are inhibited. We used two different grades of a thin-ply carbon-epoxy system to produce four different $0^{\circ}$ ply-block thicknesses ranging from $0.03 \mathrm{~mm}$ to $0.12 \mathrm{~mm}$, and measured the respective translaminar fracture toughness using compact tension tests. SEM and X-ray analysis showed no delamination nor diffuse damage. Yet, the translaminar fracture toughness increased from 46 to $104 \mathrm{~kJ} / \mathrm{m}^{2}$ (initiation), and from 49 to $160 \mathrm{~kJ} / \mathrm{m}^{2}$ (propagation), for the thickness range above. This finding has significant implications for the development and use of ply-level numerical failure models, for structural design with thin-ply composites, and for the development of thin-ply material systems.
\end{abstract}

Keywords: Thin-ply prepreg, translaminar fracture toughness, size effects, ply-blocking, SEM, X-ray.

\footnotetext{
* Corresponding author

Email address: rita.teixeira@imperial.ac.uk (R. F. Teixeira)
} 


\section{Introduction}

The ply-block thickness effect on the onset of micro-cracking and delamination has been extensively analysed [1-6]. Kim and Soni [7] investigated several quasi-isotropic layups, with different layups sequences while keeping the 5 same ratio of each constituent ply; the authors showed that the delamination threshold decreased with increasing ply-block thickness. Similarly, Wisnom et al. [8] observed significant scaling effects when changing the ply-blocks thickness in quasi-isotropic laminates. The laminates with larger ply-blocks failed by complete delamination, before fibre failure could take place. Therefore, plyblocking has been seen to result in extensive damage zones in multidirectional laminates. This creates a substantial challenge when attempting to characterize the translaminar fracture of $0^{\circ}$ plies for different $0^{\circ}$ ply-block thicknesses, using cross-ply specimens $[6,9,10]$.

Regarding the measurement of the translaminar fracture toughness of $0^{\circ}$ 15 ply-blocks, most of the work found in the literature has been bounded by a minimum ply thickness of $0.125 \mathrm{~mm}$. Published work in the literature $[4,6,9-$ 11] suggest that the translaminar fracture toughness of cross-ply laminates and of $0^{\circ}$ ply-block depends on the thickness of that ply-block. While it can be speculated that delamination may play a meaningful role in this (the extent of delamination in thick ply-block laminates is larger [10]), the analysis of the translaminar fracture surfaces of $0^{\circ}$ plies of different thicknesses reveals significant differences [10]. Additionally, an analytical model [12] which takes into account the energy dissipated by debonding and by pull-out within the ply, but neglects delamination, succeeded in predicting size effects observed by Laf-

25 fan et al. [6] and Teixeira et al. [10]. Furthermore, by considering the likely thickness-dependence of the translaminar fracture toughness, Chen et al. [13] were recently able to predict size effects observed by Green et al. [14] in ply-level blocked open hole tension specimens.

Current ply-level numerical models of material failure, either based on a 30 smeared-crack approach [15], or on partition of unity [16], rely on the translam- 
inar fracture toughness for predicting damage accumulation prior to ultimate failure. The implications of the likely dependence of the translaminar fracture toughness on the $0^{\circ}$ ply-block-thickness has therefore profound implications for the use of current numerical models.

The challenge in establishing firmly whether the translaminar fracture toughness of a $0^{\circ}$ ply-block depends on the ply-block thickness lies in that most specimen geometries (such a compact tension) cease to promote the desired failure mode when the ply thicknesses become larger than about $0.25 \mathrm{~mm}$ [10], depending on the exact material system.

Until recently, there had been little effort into reducing the ply thickness of CRFPs. Nowadays, new process methods have been developed and composite plies are now being produced with areal weights as low as $25 \mathrm{~g} / \mathrm{m}^{2}$, i.e., with a uncured ply thickness of, approximately, $0.02 \mathrm{~mm}$. From an engineering point of view, the access to thin-ply laminates has enlarged the design space, improving 45 homogenization and increasing the stacking sequences possible for a predefined laminate thickness [17-19].

Recent research on thin-ply composites [17, 18, 20-24] has shown some enhanced mechanical properties as well as size effects directly related to decreasing ply thickness. Sihn et al. [20] and Yokozeki et al. [21, 22] observed a significant reduction, and even suppression, of matrix cracking, delamination and splitting in thin-ply laminates under static, dynamic and impact loading; while standard ply thickness laminates presented considerable damage prior to failure, thin-ply laminates behaved mainly linearly. The onset of damage was delayed to close to the ultimate load in the load-bearing plies, leading to a quasi-brittle failure ${ }_{55}[17,20]$. Thus, the span between first ply failure and collapse has been drastically reduced. The analysis and understandings of translaminar fracture toughness in thin-ply composites is, therefore, even more critical than for standard ply thicknesses.

To the knowledge of the authors, no work has been published on the measurement of the translaminar fracture toughness of thin UD ply composites. Equally, there are no experimental studies on the thickness dependence of the 
translaminar fracture toughness for thicknesses lower than $0.125 \mathrm{~mm}$. The objective of this paper is to provide these first studies and the measurements mentioned.

This paper starts by introducing the thin-ply material used, the experimental method (section 2) and data reduction method (section 3). The results from X-ray imaging and microscopy are showed in section 4 and discussed in section 5. The main conclusions are drawn in section 6 .

\section{Experimental method}

\subsection{Material System}

The material system used in this work was the unidirectional (UD) prepreg TR50s/K51, 6K Pyrofil ${ }^{\circledR}$ standard modulus carbon fibre and toughened epoxy system, supplied by SkyFlex [25]. Two prepreg grades were used:

- $30 \mathrm{~g} / \mathrm{m}^{2}$ (USN 030A), low grade, with a nominal ply thickness $t^{0}=$ $0.03 \mathrm{~mm}$;

- $55 \mathrm{~g} / \mathrm{m}^{2}$ (USN 050A), high grade, with a nominal ply thickness $t^{0}=$ $0.055 \mathrm{~mm}$.

Table 1 presents the relevant material properties, where subscripts 1 and 2 denote longitudinal and transverse direction in the plane of the laminae.

\subsection{Specimen and layup configuration}

Compact tension (CT) specimens $[9,10,26]$, with layups shown in Table 2 and dimensions shown in Figure 1, were manufactured. While layup '90' (see Table 2) aimed at measuring the intralaminar fracture toughness, layups A, B, C and $\mathrm{D}$ aimed at measuring the translaminar fracture toughness for $0^{\circ}$ ply-blocks with overall thicknesses of $0.03,0.055,0.06$ and $0.11 \mathrm{~mm}$ respectively. The CT configuration was chosen as it allows a stable crack growth and the specimens are wide enough so that steady-state crack growth can be reached [9, 26, 27]. 
The ratio of $0^{\circ} / 90^{\circ}$ plies in each layup was carefully chosen to keep it as constant as possible, so that the effects of ply-blocking were isolated. The mechanical properties of each layup were calculated from Table 1 using lamination theory and can be found in Table 3 .

All laminates were manufactured using hand lay-up and cured in an autoclave according to the supplier's recommendations, as specified for the K51 resin system [25]. Once cured, a wet saw was used to cut the rectangular plates into the specimen's geometry (Figure 1). Two $8 \mathrm{~mm}$ holes were drilled using a carbide tipped drill. The specimens' notches were machined using a diamond coated disk-saw to guarantee an accurate and sharp crack tip [28]. The morphology of the crack tip, that can be typically obtained with this process, is shown in Figure 2.

\subsection{Testing and post-mortem}

At least six CT specimens for each layup (90, A, B, C and D) indicated in Table 2 were tested using an Instron machine with a $10 \mathrm{kN}$ load cell. Each specimen was loaded under displacement control, at a constant rate of $0.2 \mathrm{~mm} / \mathrm{min}$ to obtain quasi-static conditions. For each layup, the loading for one additional specimen was interrupted at approximately $90 \%$ of the respective average peak load for that layup, in order to evaluate the extension of damage at this stage.

All the inspected specimens were wedged before unloading in order to keep the fracture surfaces intact. Post-mortem analyses, such as X-ray and optical and scanning electron microscopy (SEM), enabled the identification of the damage zone, of the different damage modes, of the failure sequence, and confirmed that the crack propagated in the same plane defined by the initial notch.

$\mathrm{X}$-ray analysis was used to examine the failure modes and damage extension for the different laminates. An organic penetrant (dibromomethane) was used to highlight the damage within the specimens. The specimens were immersed in dibromomethane for 5 minutes and then dwelled for another 20. The specimens were then exposed for 140 seconds to the X-Ray tube voltage which was carefully chosen accordingly to the specimens thickness: from $18 \mathrm{kV}$ to $24 \mathrm{kV}$, as the 
thickness increased.

The crack propagation path was investigated through optical microscopy in the through-the-thickness section. For this, each ply was polished away until the reaching the ply of interest. The specimen was then placed under the microscope and thoroughly analysed.

The failure mechanisms, at the level of the ply, were characterized using a Hitachi S-3400N SEM, operating at an acceleration voltage of 5-15 kV. For this, two representative specimens of each layup were cut and attached onto aluminium stubs. Compressed air was sprayed over each specimen to remove any dust or debris traces. The specimens were sputter-coated with gold and painted on the side with silver dag to ensure electrical conductivity.

\section{Data reduction}

\subsection{Laminate fracture toughness}

The modified compliance calibration method [26, 29] was used to obtain the laminate translaminar fracture toughness from the raw test data. For each layup in Table 2, a half CT specimen was modelled using the finite element (FE) Abaqus package. A $1 \mathrm{~N}$ load was applied at the position of the loading pin. The compliance calibration curve was obtained in $1 \mathrm{~mm}$ increments of the notch length, to capture the full compliance versus crack length response, for each layup type (the elastic properties for each layup were shown in Table 3). The compliance $C$ vs. crack length $a$ data were plotted and fitted according to [30]

$$
C(a)=(\alpha a+\beta)^{\chi},
$$

where $\alpha, \beta$, and $\chi$ were calculated to best fit the experimental data for each layup. Further details on the finite element model can be found in [31]. The parameters $\alpha, \beta$ and $\chi$ for each layup are listed in Table 4 .

For the fracture toughness tests, an effective crack length, $a_{\text {eff }}$, could be determined using the elastic compliance measured from the load vs. displacement 
curve of the test specimens, and the $\alpha, \beta$ and $\chi$ constants obtained numerically:

$$
a_{\mathrm{eff}}=\frac{C^{\frac{1}{\chi}}-\beta}{\alpha}
$$

The translaminar fracture toughness for each laminate was then be calculated as:

$$
G_{\mathrm{Ic}}^{\mathrm{Lam}}=\frac{P_{c}^{2}}{2 t} \frac{\mathrm{d} C}{\mathrm{~d} a}
$$

where $P_{c}$ is the measured load that initiates or propagates fracture and $t$ is the specimen's thickness.

One of the main advantages of this data reduction method is that it does not rely on the observation of the surface of the specimen [29]. This is important as the external plies of the specimen do not necessarily reflect the actual crack front inside the specimen during crack growth; the crack front is not necessarily uniform through the thickness of the specimen, and delamination (as well as other damage) near the crack front may influence the strain field at the surface.

Three different toughnesses were measured in this work: non-linearity onset, initiation and propagation. The non-linearity onset was defined at the point where the load-displacement curve ceases being perfectly linear. An initiation value was calculated through a linear regression of toughness values between the non-linearity onset and propagation (see Section 4.3). The propagation toughness was defined as the average of the toughness values, once the $R$-curve had levelled out (steady-state).

\subsection{Ply fracture toughness}

For the $90^{\circ}$ laminate (layup '90' in Table 2), the laminate toughness obtained from Equation 3 corresponds immediately to the $90^{\circ}$ ply intralaminar toughness, $G_{\text {Ic }}^{90}$. For the other layups (layups A, B, C and D in Table 2), the fracture toughness of the $0^{\circ}$ plies was obtained from the rule of mixtures as

$$
G_{\mathrm{Ic}}^{0}=\frac{G_{\mathrm{Ic}}^{\mathrm{Lam}} t^{\mathrm{Lam}}-G_{\mathrm{Ic}}^{90} t_{\mathrm{T}}^{90}}{t_{\mathrm{T}}^{0}}
$$


where $t^{\text {Lam }}$ is the thickness of the laminate, $t_{\mathrm{T}}^{0}$ is the total thickness of all the $0^{\circ}$ plies of the laminate, and $t_{\mathrm{T}}^{90}$ is the total thickness of the $90^{\circ}$ plies in the 170 laminate $\left(\right.$ note $\left.t^{\mathrm{Lam}}=t_{\mathrm{T}}^{0}+t_{\mathrm{T}}^{90}\right)$.

\section{Results}

\subsection{Load-displacement curves}

Except for the UD layup ('90' in Table 2), all laminates exhibited a stickslip crack growth, typical of cross-ply laminates (see Figure 3, where $d$ is the displacement). Despite the fact that all cross-ply layups (A, B, C and D) have a very similar $0^{\circ} / 90^{\circ}$ ply ratio, the size of the load-drops visible in the loaddisplacement curves was significantly dependent on the thickness of the $0^{\circ}$ plyblock $\left(t^{0}\right)$. The crack propagated more smoothly (higher number of smaller load-drops) in the blocked configurations. Both for the low graded (layups A and $\mathrm{C}$ ) and the high graded material (layups B and D), the peak load can be observed to increase with ply-block thickness (see Figure 3).

\subsection{Post-mortem}

\subsubsection{X-ray}

The damage extension was investigated via X-ray imaging, as shown in Fig-

ures 4 and 5 . The X-ray images in Figure 4 were taken from layups where specimens were loaded until, approximately, $90 \%$ of the average peak load had been reached, whilst those in Figure 5 were taken from fully tested specimens.

The height of the damaged zone is very small in all cases, but it is larger for layup D, for which the ply-block thickness is relatively similar to that of classical thickness prepregs.

\subsubsection{Optical microscopy}

One representative micrograph for each cross-ply layup is presented in Figure 6. It can be seen that the crack path remained coplanar with the initial notch tip plane. 


\subsubsection{Scanning electron microscopy}

A more detailed analysis of the failure process was done via SEM imaging of the fracture surfaces, as shown in Figures 7 to 10. The crack front corresponding to each load-drop was easily observable, even to the naked eye, from the fractured surfaces in all four CP layups (Figure 7). The pull-out height is visible in Figures 8 and 9, while the top view in Figure 10 provides greater insight into the translaminar fracture surface across the thickness of the ply. The fibre/matrix interface and the resin rich-region between plies can be gleaned from Figure 9 .

\subsection{Laminate and ply fracture toughnesses}

\subsubsection{Intralaminar fracture toughness}

\subsubsection{Translaminar fracture toughnesses}

For each CP specimen (layups A, B, C and D in Table 2), three toughness values were measured: non-linearity onset, initiation and propagation. All three toughnesses are presented in Table 5 for the laminate level, and in Table 6 at level of the ply-block. Figure 11 presents the full $R$-curves for all CP laminates. The ply-level toughnesses measured, for all four layups, were overlapped in Figure 12 and are presented as a function of the ply thickness in Figure 13. When using Equation (4), the initiation value $G_{\mathrm{Ic}}^{90}$ was used. It should be noted that the term $G_{\text {Ic }}^{90}$ could even be omitted without loss of accuracy, since $G_{\text {Ic }}^{90} \ll G_{\text {Ic }}^{0}$.

\section{Discussion}

Fully-tested specimens revealed a thin crack path, well aligned with the notch tip, and reduced splitting (Figures 5 and 6 ). 
The thickness of $0^{\circ}$ ply-blocks was seen to influence the size of the load-drops and, therefore, crack growth stability. Specimens with a thicker $0^{\circ}$ ply-block typically exhibited more populated load-displacement curves and, consequently, SEMs in Figures 9 and 10 show very clearly that delamination was successfully inhibited, and that, therefore, the ply-block thickness effect measured is not due 
to delamination.

The width of the damage zone increases slightly but visibly with the ply numerical modelling and development of thin-ply material systems. 


\section{Conclusions}

Using compact tension tests on cross-ply thin-ply carbon-epoxy UD speci-

285

290

mens, this work demonstrated that:

- the translaminar fracture toughness in fibre-reinforced laminated composites, as well as the $R$-curve effect, depend significantly on the thickness of the $0^{\circ}$ ply blocks (it is therefore not an absolute, but rather in-situ, property);

- for the materials tested in this study (with $0^{\circ}$ ply-block thicknesses ranging from $0.03 \mathrm{~mm}$ to $0.12 \mathrm{~mm}$ ), the translaminar fracture toughness increased from 46 to $104 \mathrm{~kJ} / \mathrm{m}^{2}$ (initiation), and from 49 to $160 \mathrm{~kJ} / \mathrm{m}^{2}$ (propagation);

- for the materials tested in this study, these increases cannot be attributed to delamination nor diffuse damage;

- for the materials tested in this study, these increases can be attributed to the lengths of the several scales of pulled-out fibres and bundles of fibres, visible through-the-thickness of the plies, which increase with $0^{\circ}$ ply-block thickness;

- while thin-ply composites may offer superior damage-onset strength (when compared to standard ply thicknesses), the brittleness that entails must be carefully considered when designing with these materials;

- analytical and numerical ply-level damage propagation models used for design and damage-tolerance analysis should either include $0^{\circ}$ ply-blockthickness-dependent translaminar fracture toughness, or use directly a value of translaminar fracture toughness appropriate for the ply-block thickness being considered. 


\section{Acknowledgements}

The funding from the Portuguese Foundation for Science and Technology

310

knowledged. The authors are also thankful to Dr. Steve Harrison from Triple

$\mathrm{H}$ Composites for providing the material used on this work along with the corresponding technical data.

\section{References}

[5] M. . R. Wisnom, S. R. Hallett, Experimental investigation of progressive damage and the effect of layup in notched tensile tests, Journal of Composites Materials 40 (2006) 119-141.

[6] M. J. Laffan, S. T. Pinho, P. Robinson, L. Iannucci, Measurement of the

[1] K. M. Prewo, The effect of ply lay-up sequence on the fracture toughness of boron aluminum, Journal of Composite Materials 12 (1978) 40-52.

[2] C. E. Harris, D. H. Morris, Fracture behaviour of thick, laminated graphite/epoxy composites, Tech. Rep. NASA Contractor Report 3784, Virginia Polytechnic Institute and State University (1984).

[3] C. E. Harris, D. H. Morris, A comparison of the fracture behaviour of thick laminated composites utilizing compact tension, three-point bend and centre-cracked tension specimens, Tech. Rep. ASTM STP 905, Fracture Mechanics: seventh volume (1986).

[4] R. S. Vaidya, C. T. Sun, Fracture criterion for notched thin composite laminates, AIAA Journal 35 (1997) 311-316.

in situ ply fracture toughness associated with mode I fibre tensile failure in FRP. Part II:Size and lay-up effects, Composites Science and Technology 70(4) (2010) 614-621. 
[7] R. Y. Kim, S. R. Soni, Experimental and analytical studies on the onset of delamination in laminated composites, Journal of composite Materials 18 (1984) 70-80.

[8] M. R. Wisnom, S. R. Hallett, C. Soutis, Scaling effects in notched composites, Journal of Composite Materials 44 (2010) 195-210.

[9] S. T. Pinho, P. Robinson, L. Iannucci, Fracture toughness of the tensile and compressive fibre failure modes in laminated composites, Composites Science and Technology 66 (2006) 2069-2079.

[10] R. F. Teixeira, S. T. Pinho, P. Robinson, Translaminar fracture toughness of CFRP: From the toughness of individual plies to the toughness of the laminates, $15^{\text {th }}$ European Conference on Composite Materials (ECCM15).

[11] X. Li, S. R. Hallett, M. R. Wisnom, N. Zobeiry, R. Vaziri, A. Poursartip, Experimental study of damage propagation in over-height compact tension tests, Composites: Part A 40 (2009) 1891-1899.

[12] S. Pimenta, S. T. Pinho, An analytical model for the translaminar fracture toughness of fibre composites with stochastic quasi-fractal fracture surfaces, Journal of the Mechanics and Physics of Solids 66 (2014) 78-102.

350 [13] B. Y. Chen, , T. Tay, P. Baiz, S. Pinho, Numerical analysis of size effects on open-hole tensile composite laminates, Composites: Part A 47 (2013) $52-62$.

[14] B. G. Green, M. R. Wisnom, S. R. Hallett, An experimental investigation into the tensile strength scaling of notched composites, Composites Part A 38 (2006) 867-878.

[15] S. T. Pinho, L. Iannucci, P. Robinson, Physically-based failure models and criteria for laminated fibre-reinforced composites with emphasis on fibre kinking: Part ii: Fe implementation, Composites Part A 37 (2006) 766-777. 
[16] E. Iarve, M. Gurvich, D. Mollenhauer, C. Rose, C. Dávila, Meshindependent matrix cracking and delamination modeling in laminated composites, International Journal for Numerical Methods in Engineering 88 (8) (2011) 749-773.

[17] S. W. Tsai, M. Papila, Homogenization made easy with bi-angle thin-ply ncf, JEC Composites Magazine 68 (2011) 70-1.

[18] G. Guillamet, A. Turon, J. Costa, J. Renart, P. Linde, J. Mayugo, Damage occurrence at edges of non-crimp-fabric thin-ply laminates under off-axis uniaxial loading, Composites Science and Technology 67 (2014) 996-1008.

[19] G. Czél, M. R. Wisnom, Demonstration of pseudo-ductility in high performance glass/epoxy composites by hybridisation with thin-ply carbon prepreg, Composites: Part A 52 (2013) 23-30.

[20] S. Sihn, R. Y. Kim, K. Kawabe, S. W. Tsai, Experimental studies of thinply laminated composites, Composites Science and Technology 67 (2007) 996-1008.

375 [21] T. Yokozeki, Y. Aoki, T. Ogasawara, Experimental characterization of strength and damage resistance properties of thin-ply carbon fiber/toughened epoxy laminates, Composite Structures 82 (2008) 382-389.

[22] T. Yokozeki, A. Kuroda, A. Yoshimura, T. Ogasawara, T. Aoki, Damage characterization in thin-ply composite laminates under out-of-plane transverse loadings, Composite Structures 93 (2010) 49-57.

[23] R. Amacher, J. Cugnoni, J. Botsis, L. Sorensen, W. Smith, C. Dransfeld, Thin ply composites: Experimental characterization and modelling of sizeeffects, Composites Science and Technology 101 (2014) 121-132.

[24] A. Arteiro, G. Catalanotti, J. Xavier, P. Camanho, Notched response of non-crimp fabric thin-ply laminates, Composites Science and Technology 79 (2013) 97--114. 
[25] Skyflex, K51 Epoxy prepreg technical datasheet (2013).

[26] M. J. Laffan, S. T. Pinho, P. Robinson, A. J. McMillan, Translaminar Fracture Toughness Testing: A Review, Polymer Testing 31 (2012) 481489.

[27] N. Blanco, S. T. Pinho, Parametric analysis of different compact tension specimens for fracture toughness characterisation in woven composite materials, Tech. rep., Imperial College London Report (2008).

[28] M. J. Laffan, S. T. Pinho, P. Robinson, L. Iannucci, Effects of notch tip radius on the translaminar fracture toughness of cross-ply carbon/epoxy laminates, Composites Science and Technology 72 (2012) 97-102.

[29] M. J. Laffan, S. T. Pinho, P. Robinson, L. Iannucci, Measurement of the in situ ply fracture toughness associated with mode I fibre tensile failure in FRP. Part I: Data Reduction, Composites Science and Technology 70(4) (2010) 606-613.

[30] C. Dávila, C. Rose, P. Camanho, A procedure for superposing linear cohesive laws to represent multiple damage mechanisms in the fracture of composites, International Journal of Fracture 158(2) (2009) 211-223.

[31] R. F. Teixeira, Translaminar fracture toughness of cfrp: from the toughness of individual plies to the toughness of the laminate, Ph.D. thesis, Imperial College of London (2015).

[32] E. Greenhalgh, Failure analysis and fractography of polymer composites, Woodhead Publishing Limited, 2009. 
Table 1. TR50s/K51 properties provided by Skyflex [25].

\begin{tabular}{|c|c|c|}
\hline Single fibre diameter $[\mu \mathrm{m}]$ & \multicolumn{2}{|c|}{6.82} \\
\hline Nominal ply thickness [mm] & 0.03 & 0.055 \\
\hline Fibre areal weight $\left[\mathrm{g} / \mathrm{m}^{2}\right]$ & 30 & 55 \\
\hline Fibre volume fraction $[\%]$ & 55 & 55 \\
\hline Cured resin density $\left[\mathrm{g} / \mathrm{cm}^{3}\right]$ & & \\
\hline Fibre density $\left[\mathrm{g} / \mathrm{cm}^{3}\right]$ & & \\
\hline Nominal laminate density $\left[\mathrm{g} / \mathrm{cm}^{3}\right]$ & & \\
\hline Longitudinal modulus $E_{1}[\mathrm{GPa}]$ & & \\
\hline Transverse modulus $E_{2}[\mathrm{GPa}]$ & & \\
\hline Major Poisson's ratio $\nu_{12}$ & & \\
\hline Shear modulus $G_{12}[\mathrm{GPa}]$ & & \\
\hline
\end{tabular}

Table 2. Thin-ply layups investigated. $0^{\circ}$ is aligned with the direction of the applied load.

\begin{tabular}{ccccccc}
\hline ID & $\begin{array}{c}\text { Material } \\
\text { Grade }\end{array}$ & Layup & $\begin{array}{c}\text { Purpose } \\
\text { of layup }\end{array}$ & $\begin{array}{c}t^{0 \mathrm{a}} \\
{[\mathrm{mm}]}\end{array}$ & $\begin{array}{c}t^{\text {Lam b }} \\
{[\mathrm{mm}]}\end{array}$ & $\begin{array}{c}\text { Number } \\
\text { of plies }\end{array}$ \\
\hline 90 & $\mathrm{H}$ & {$[90]_{54}$} & $G_{\mathrm{Ic}}^{90}$ & - & 3.00 & 54 \\
\hline $\mathrm{A}$ & $\mathrm{L}$ & {$\left[90_{3} /(90 / 0)_{24} / 90_{2}\right]_{s}$} & $G_{\mathrm{Ic}}^{0}$ & 0.0307 & 3.25 & 106 \\
$\mathrm{~B}$ & $\mathrm{H}$ & {$\left[90_{2} /(90 / 0)_{16} / 90\right]_{s}$} & $G_{\mathrm{Ic}}^{0}$ & 0.0544 & 3.81 & 70 \\
\hline $\mathrm{C}$ & $\mathrm{L}$ & {$\left[90_{3} /\left(90_{2} / 0_{2}\right)_{12} / 90_{2}\right]_{s}$} & $G_{\mathrm{Ic}}^{0}$ & $2 \times 0.0306=0.0612$ & 3.24 & 106 \\
$\mathrm{D}$ & $\mathrm{H}$ & {$\left[90_{2} /\left(90_{2} / 0_{2}\right)_{8} / 90\right]_{s}$} & $G_{\mathrm{Ic}}^{0}$ & $2 \times 0.0547=0.1094$ & 3.83 & 70 \\
& & & & & & \\
\hline
\end{tabular}

${ }^{a}$ Measured $0^{\circ}$ ply block thickness; calculated from the averaged total thickness of all the respective specimens.

b Measured laminate thickness; averaged from all respective specimens.

Table 3. Laminates' elastic properties calculated from lamination theory.

\begin{tabular}{cccccc}
\hline Layup ID & Layup & $E_{x}[\mathrm{GPa}]$ & $E_{y}[\mathrm{GPa}]$ & $\nu_{x y}$ & $\mathrm{G}_{x y}[\mathrm{GPa}]$ \\
\hline 90 & {$\left[90_{54}\right]$} & 125.3 & 8.4 & 0.019 & 5.1 \\
$\mathrm{~A}$ & {$\left[90_{3} /(90 / 0)_{24} / 90_{2}\right]_{s}$} & 72.87 & 61.77 & 0.038 & 5.1 \\
$\mathrm{~B}$ & {$\left[90_{2} /(90 / 0)_{16} / 90\right]_{s}$} & 72.14 & 62.10 & 0.038 & 5.1 \\
$\mathrm{C}$ & {$\left[90_{3} /\left(90_{2} / 0_{2}\right)_{12} / 90_{2}\right]_{s}$} & 72.87 & 61.77 & 0.038 & 5.1 \\
$\mathrm{D}$ & {$\left[90_{2} /\left(90_{2} / 0_{2}\right)_{8} / 90\right]_{s}$} & 72.14 & 62.10 & 0.038 & 5.1 \\
\hline
\end{tabular}


Table 4. Numerical fitting parameters used in the modified compliance method (units system: $\mathrm{N} ; \mathrm{mm})$.

\begin{tabular}{ccccc}
\hline Layup ID & Layup & $\alpha$ & $\beta$ & $\chi$ \\
\hline 90 & {$[90]_{54}$} & -0.0366 & 1.9636 & -0.3676 \\
$\mathrm{~A}$ & {$\left[90_{3} /(90 / 0)_{24} / 90_{2}\right]_{s}$} & -0.0531 & 2.8230 & -0.4390 \\
$\mathrm{~B}$ & {$\left[90_{2} /(90 / 0)_{16} / 90\right]_{s}$} & -0.0570 & 3.0359 & -0.4390 \\
$\mathrm{C}$ & {$\left[90_{3} /\left(90_{2} / 0_{2}\right)_{12} / 90_{2}\right]_{s}$} & -0.0531 & 2.8230 & -0.4390 \\
$\mathrm{D}$ & {$\left[90_{2} /\left(90_{2} / 0_{2}\right)_{8} / 90\right]_{s}$} & -0.0570 & 3.0359 & -0.4390 \\
\hline
\end{tabular}

Table 5. Average laminate level critical energy release rates.

\begin{tabular}{ccccc}
\hline Layup & $\begin{array}{c}t^{0} \\
{[\mathrm{~mm}]}\end{array}$ & $\begin{array}{c}G_{\mathrm{Ic}}^{\mathrm{Lam}} \\
\text { Non-linearity } \\
\text { onset }\left[\mathrm{kJ} / \mathrm{m}^{2}\right] \\
(\mathrm{CoV}[\%])\end{array}$ & $\begin{array}{c}G_{\mathrm{Ic}}^{\text {Lam }} \\
\text { Initiation } \\
{\left[\mathrm{kJ} / \mathrm{m}^{2}\right]} \\
(\mathrm{CoV}[\%])\end{array}$ & $\begin{array}{c}G_{\mathrm{Ic}}^{\text {Lam }} \\
\text { Propagation } \\
{\left[\mathrm{kJ} / \mathrm{m}^{2}\right]} \\
(\mathrm{CoV}[\%])\end{array}$ \\
\hline 90 & - & 0.220 & 0.255 & - \\
{$[90]_{54}$} & $(7.45)$ & $(11.92)$ & $(-)$ \\
\hline $\mathrm{A}$ & 0.03 & $(7.40)$ & 20.85 & 22.82 \\
{$\left[90_{3} /(90 / 0)_{24} / 90_{2}\right]_{s}$} & & 16.19 & 26.75 & 43.43 \\
\hline $\mathrm{B}$ & 0.055 & $(7.3)$ & $(2.0)$ & $(4.0)$ \\
\hline$\left[90_{2} /(90 / 0)_{16} / 90\right]_{s}$ & & 19.78 & 24.79 & 32.30 \\
$\mathrm{C}$ & 0.06 & $(9.47)$ & $(8.86)$ & $(12.07)$ \\
\hline$\left[90_{3} /\left(90_{2} / 0_{2}\right)_{12} / 90_{2}\right]_{s}$ & & 16.62 & 44.59 & 73.40 \\
\hline $\mathrm{D}$ & 0.11 & $(13.6)$ & $(7.4)$ & $(9.2)$ \\
\hline$\left[90_{2} /\left(90_{2} / 0_{2}\right)_{8} / 90\right]_{s}$ & & & &
\end{tabular}

Table 6. Average ply-block level values of critical energy release rates.

\begin{tabular}{ccccc}
\hline Layup & $\begin{array}{c}t^{0} \\
{[\mathrm{~mm}]}\end{array}$ & $\begin{array}{c}G_{\mathrm{Ic}}^{0} \\
\text { Non-linearity } \\
\text { onset }\left[\mathrm{kJ} / \mathrm{m}^{2}\right] \\
(\mathrm{CoV}[\%])\end{array}$ & $\begin{array}{c}G_{\mathrm{Ic}}^{0} \\
\text { Initiation } \\
{\left[\mathrm{kJ} / \mathrm{m}^{2}\right]} \\
(\mathrm{CoV}[\%])\end{array}$ & $\begin{array}{c}G_{\mathrm{Ic}}^{0} \\
\text { Propagation } \\
{\left[\mathrm{kJ} / \mathrm{m}^{2}\right]} \\
(\mathrm{CoV}[\%])\end{array}$ \\
\hline $\mathrm{A}$ & 0.03 & $\begin{array}{c}32.86 \\
(7.48)\end{array}$ & $\begin{array}{c}45.86 \\
(8.54)\end{array}$ & $\begin{array}{c}49.16 \\
(10.91)\end{array}$ \\
\hline$\left[90_{3} /(90 / 0)_{24} / 90_{2}\right]_{s}$ & & 35.10 & 58.19 & 94.30 \\
$\mathrm{~B}$ & 0.055 & $(7.39)$ & $(2.00)$ & $(3.58)$ \\
\hline$\left[90_{2} /(90 / 0)_{16} / 90\right]_{s}$ & & 43.37 & 54.44 & 71.03 \\
\hline $\mathrm{C}$ & 0.06 & $(9.54)$ & $(8.91)$ & $(12.12)$ \\
\hline$\left[90_{3} /\left(90_{2} / 0_{2}\right)_{12} / 90_{2}\right]_{s}$ & & 36.06 & 97.23 & 160.25 \\
\hline $\mathrm{D}$ & 0.11 & $(13.70)$ & $(7.39)$ & $(9.24)$ \\
\hline$\left[90_{2} /\left(90_{2} / 0_{2}\right)_{8} / 90\right]_{s}$ & 0
\end{tabular}




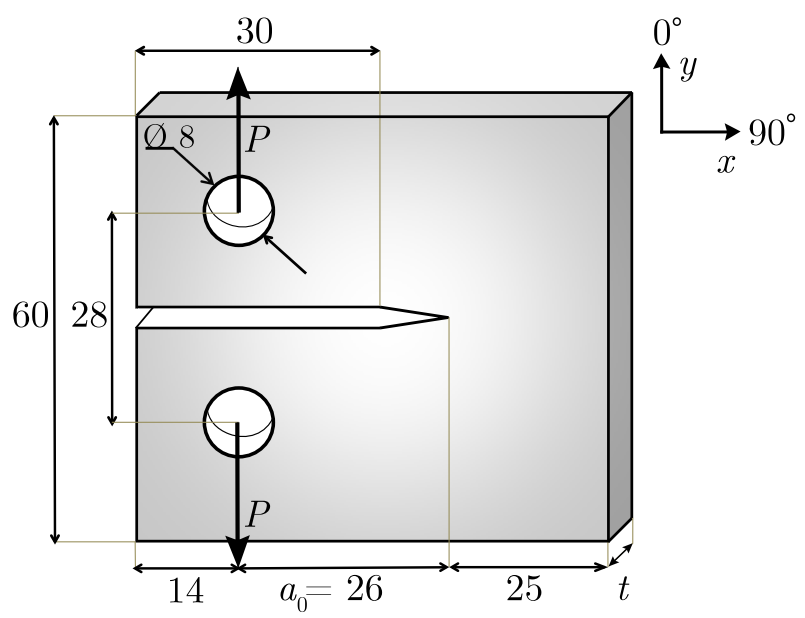

Figure 1. CT specimens dimensions and fibre directions. All dimensions are in $\mathrm{mm}$.

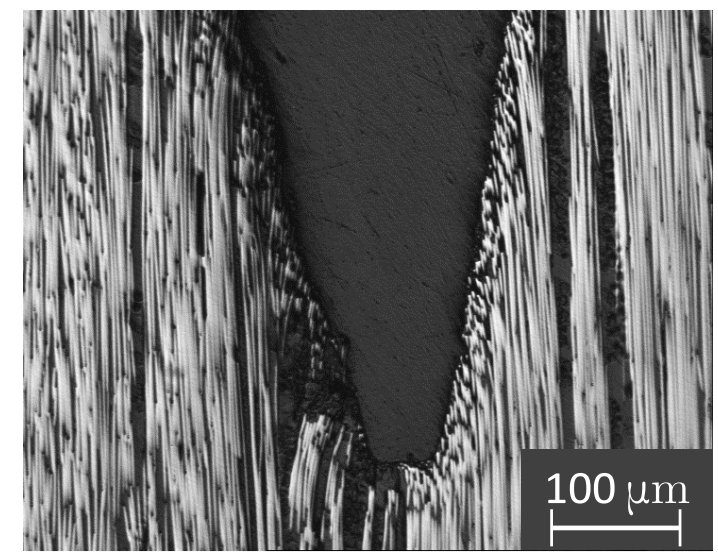

Figure 2. CT crack tip morphology obtained using an optical microscope. 


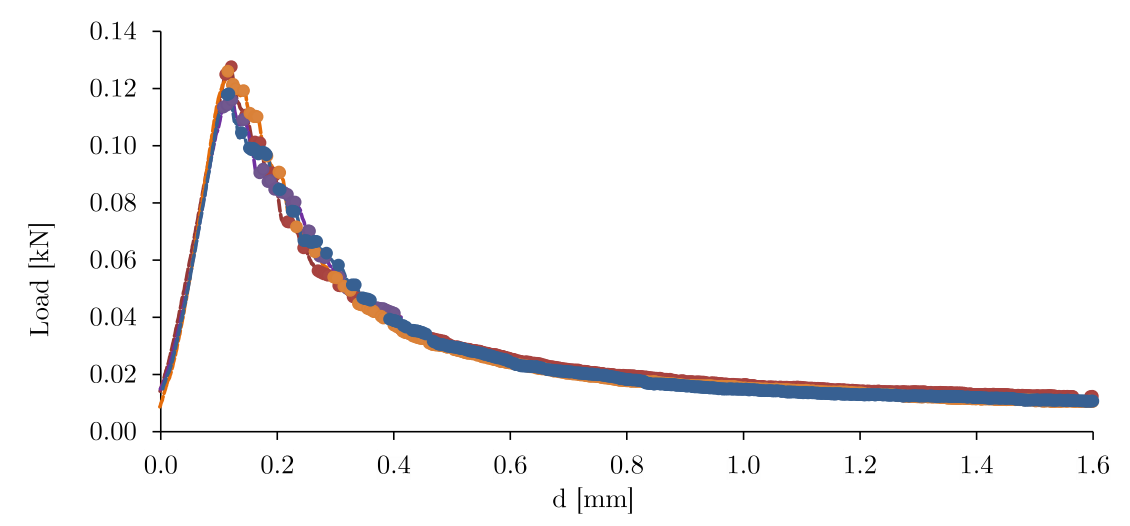

(a) Layup 90



(b) Layup A: $t^{0}=0.03 \mathrm{~mm}$

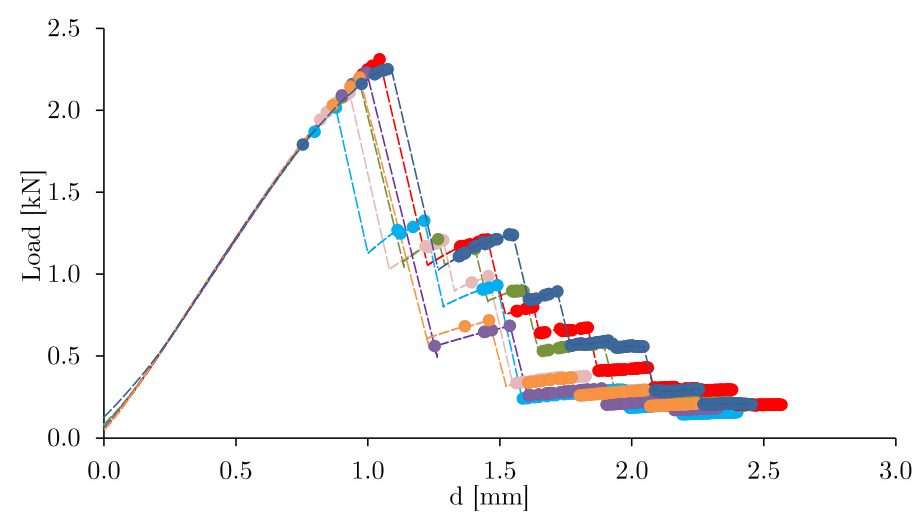

(d) Layup C: $t^{0}=2 \times 0.03=0.06 \mathrm{~mm}$

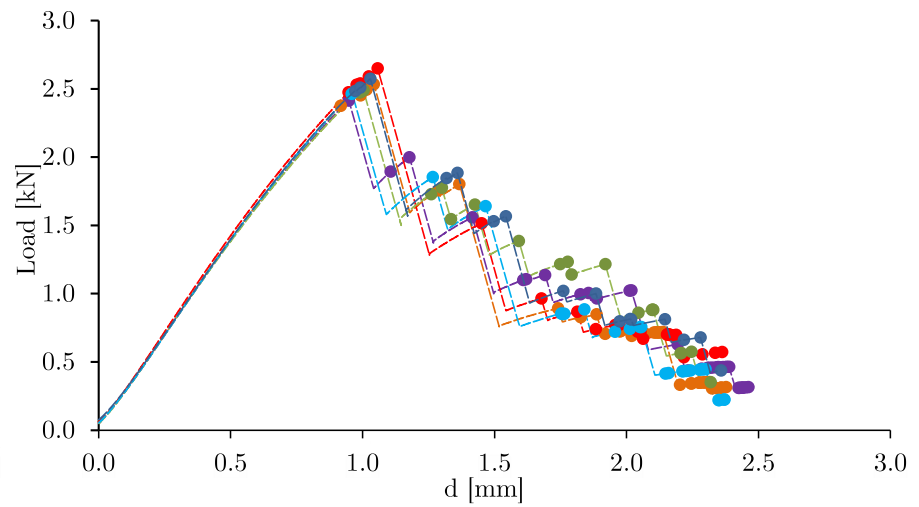

(c) Layup B: $t^{0}=0.055 \mathrm{~mm}$

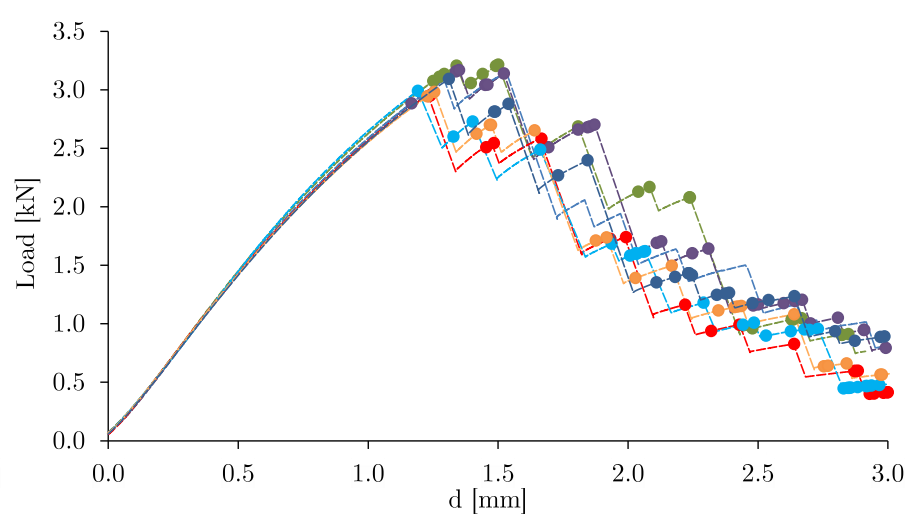

(e) Layup D: $t^{0}=2 \times 0.055=0.11 \mathrm{~mm}$

Figure 3. Typical experimental load-displacement curves for thin-ply laminates. The circles highlight points at which load-drops (even if very small) took place. 


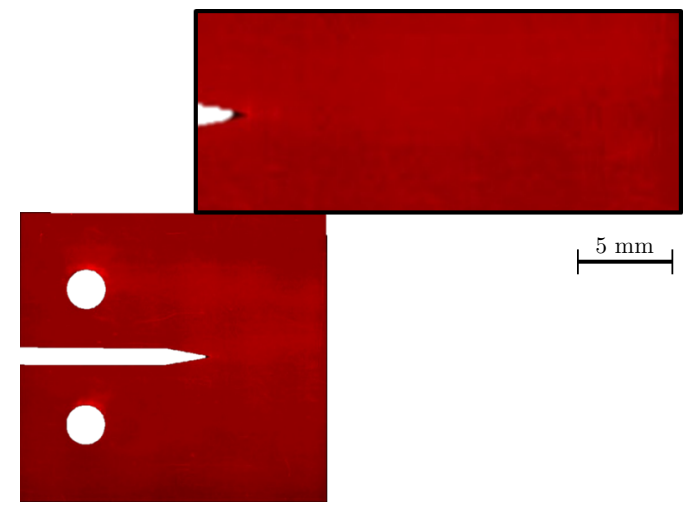

(a) Layup 90 at $P=0.15 \mathrm{kN}$

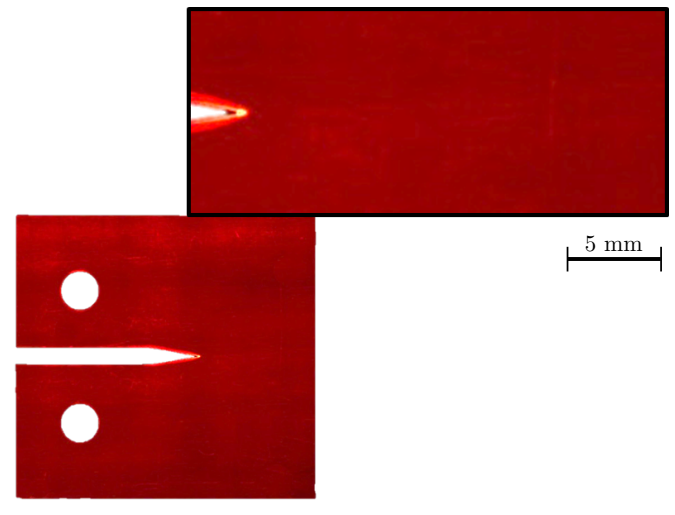

(b) Layup A: $t^{0}=0.03 \mathrm{~mm}$, at $P=1.91 \mathrm{kN}$

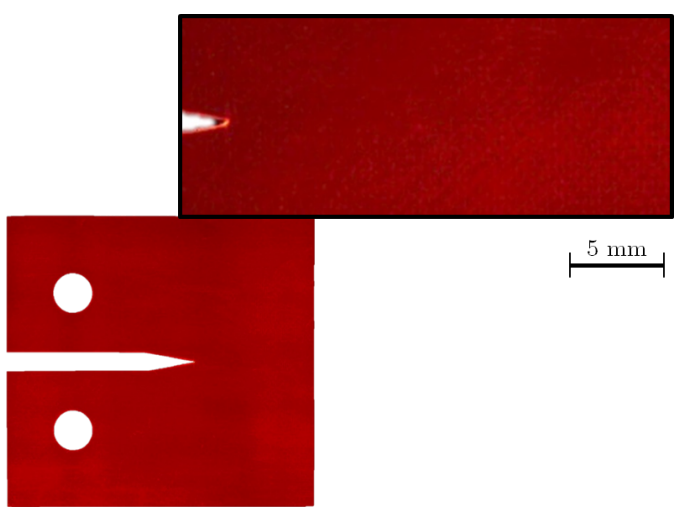

(d) Layup C: $t^{0}=2 \times 0.03=0.06 \mathrm{~mm}$, at $P=1.72 \mathrm{kN}$

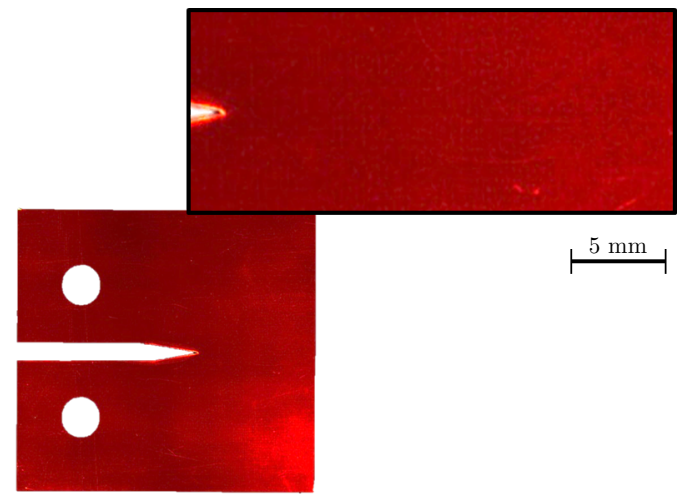

(c) Layup B: $t^{0}=0.055 \mathrm{~mm}$, at $P=2.40 \mathrm{kN}$

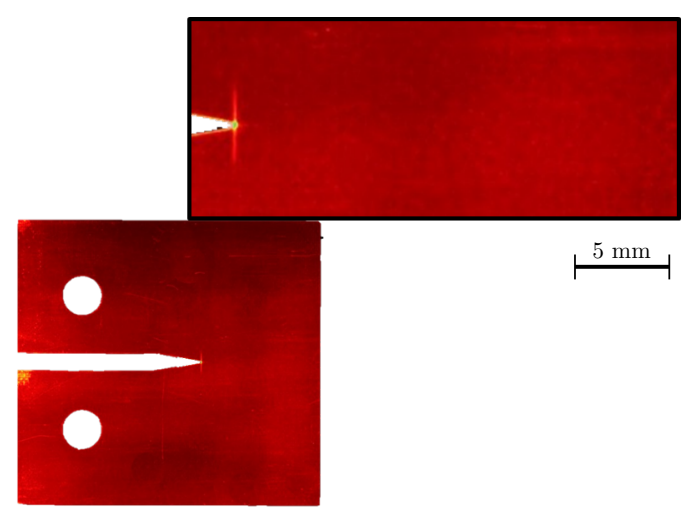

(e) Layup D: $t^{0}=2 \times 0.055=0.11 \mathrm{~mm}$, at $P=3.06 \mathrm{kN}$

Figure 4. X-ray imaging of thin-ply laminates shows none or minor damage prior to peak load $P_{\text {max }}$. Inset: magnification near the notch tip. 


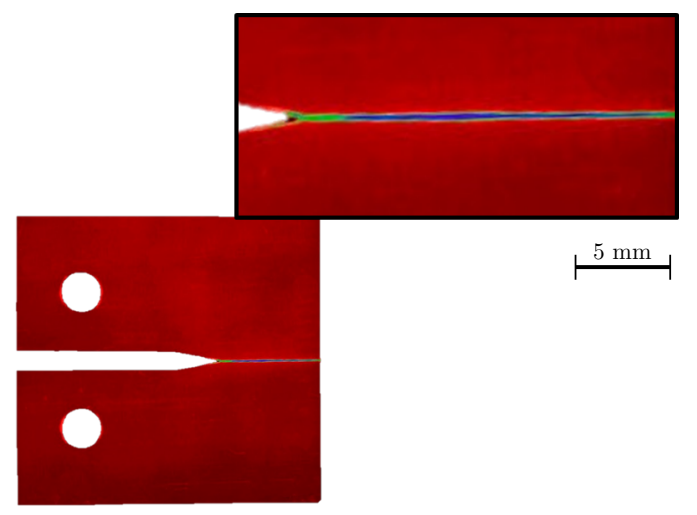

(a) Layup 90

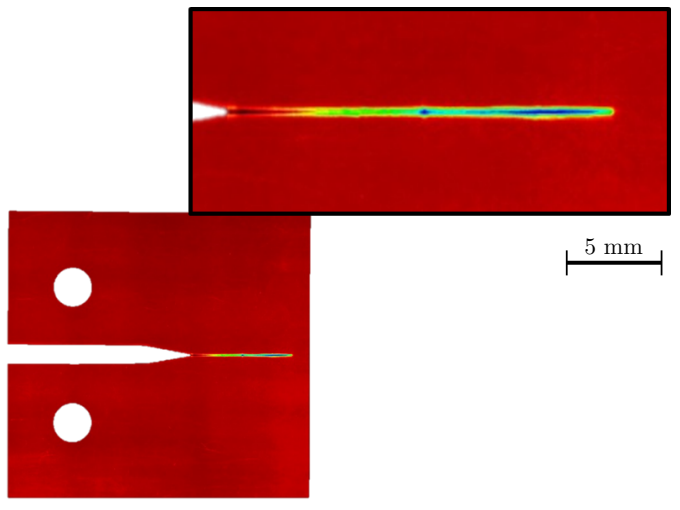

(b) Layup A: $t^{0}=0.03 \mathrm{~mm}$

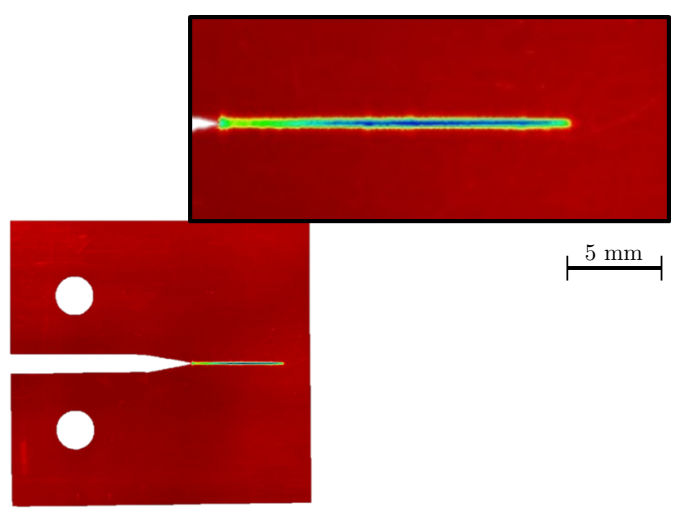

(d) Layup C: $t^{0}=2 \times 0.03=0.06 \mathrm{~mm}$

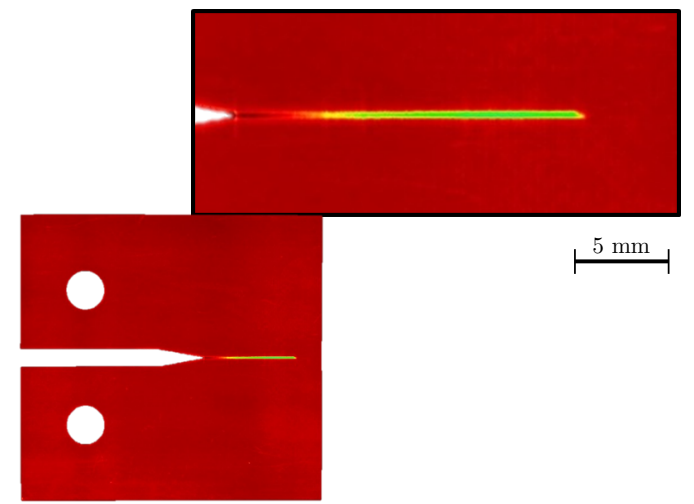

(c) Layup B: $t^{0}=0.055 \mathrm{~mm}$

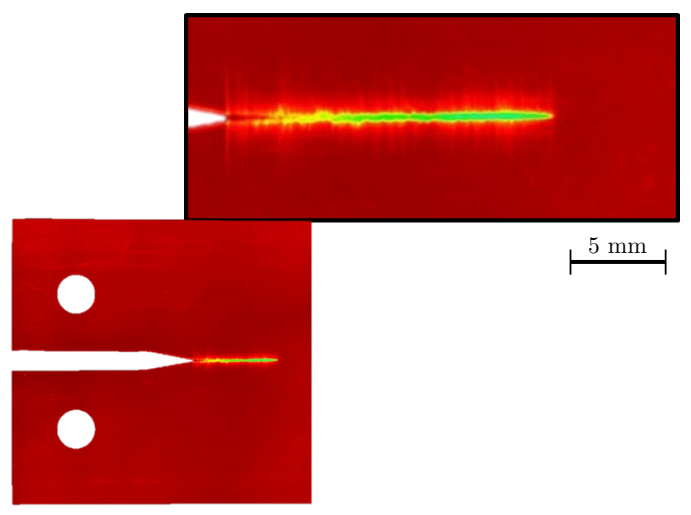

(e) Layup D: $t^{0}=2 \times 0.055=0.11 \mathrm{~mm}$

Figure 5. X-ray imaging shows the damage after testing. The blocking of $0^{\circ}$ plies does not lead to considerable diffuse damage. Inset: magnification near the notch tip. 

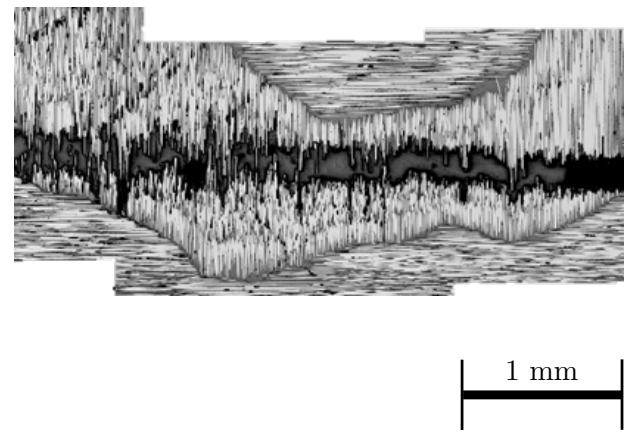

(a) Layup A: $t^{0}=0.03 \mathrm{~mm}$

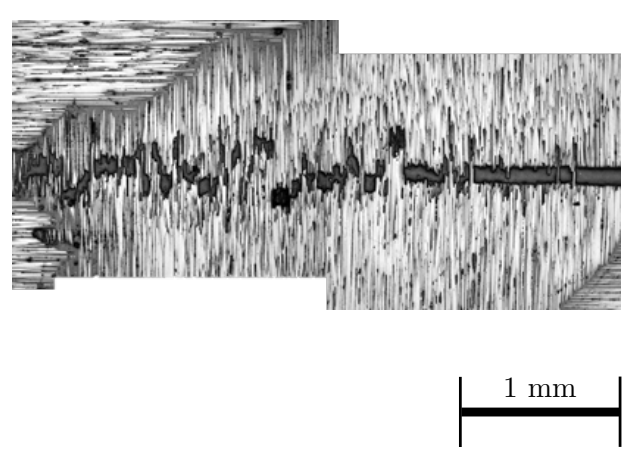

(c) Layup C: $t^{0}=2 \times 0.03=0.06 \mathrm{~mm}$

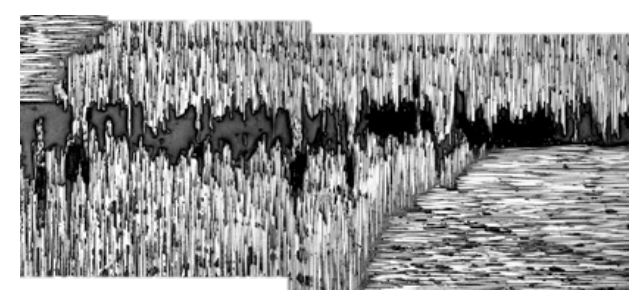

$1 \mathrm{~mm}$

(b) Layup B: $t^{0}=0.055 \mathrm{~mm}$
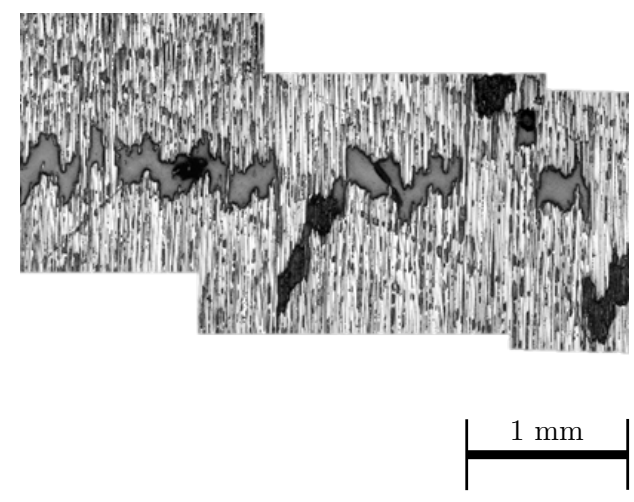

(d) Layup D: $t^{0}=2 \times 0.055=0.11 \mathrm{~mm}$

Figure 6. Micrographs of CP thin-ply laminates show a stepped crack path. The size of the steps increases when blocking $0^{\circ}$ plies. 


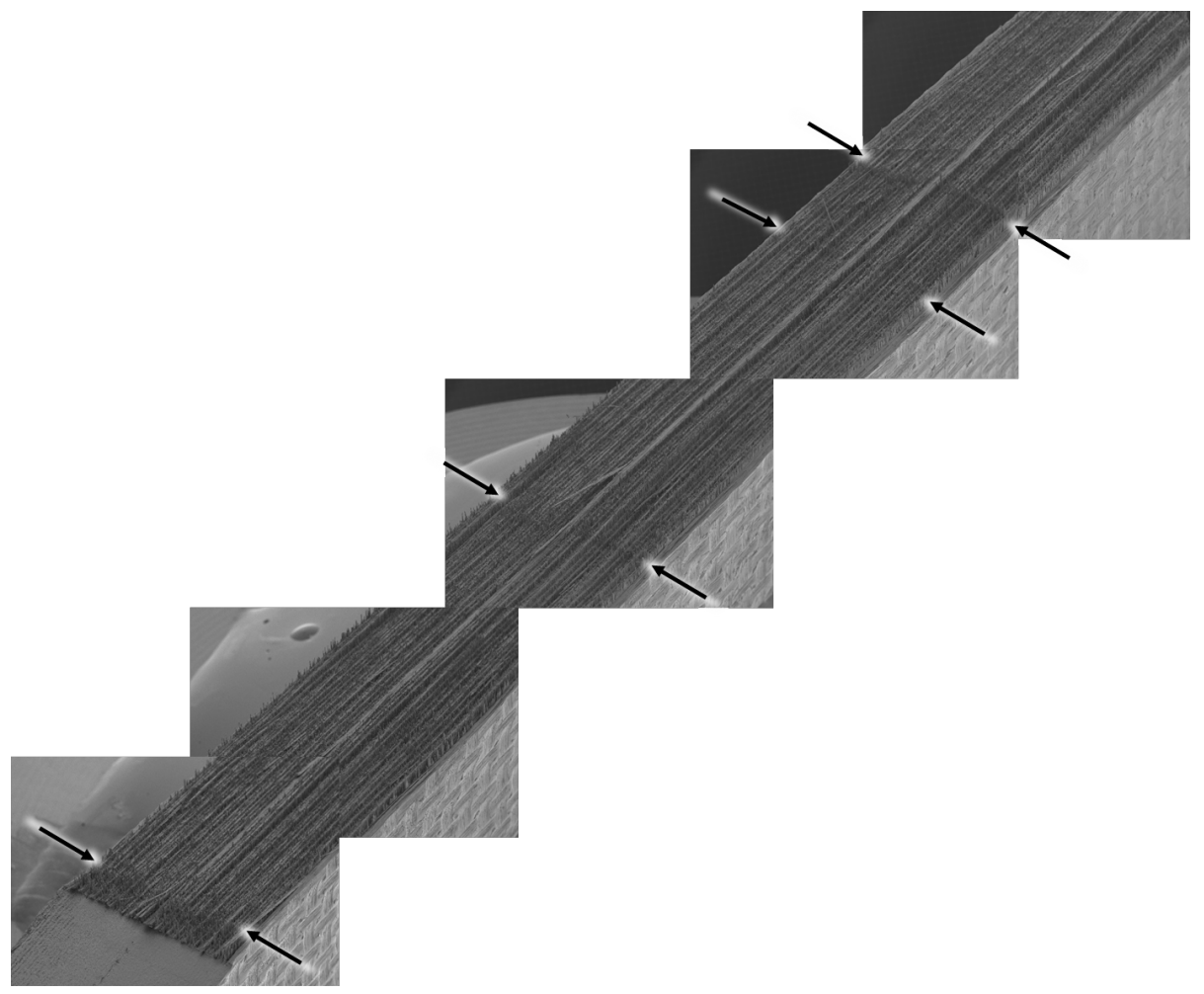

Figure 7. Fractured surface for layup A showing that the shape of the crack front is visible at each crack arrest location. Crack propagates from the bottom left corner to the right top corner. 


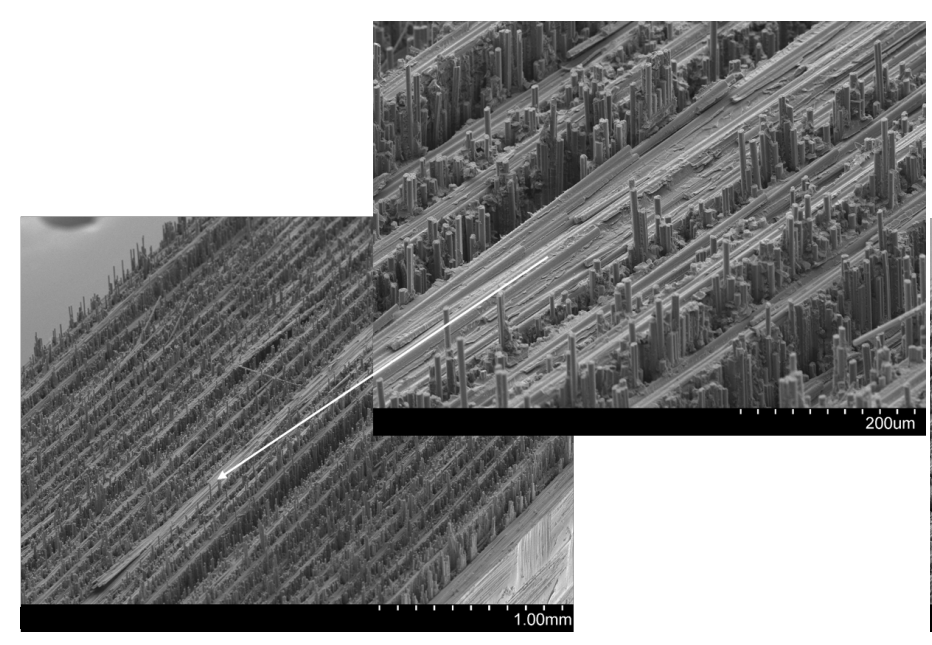

(a) Layup A: $t^{0}=0.03 \mathrm{~mm}$

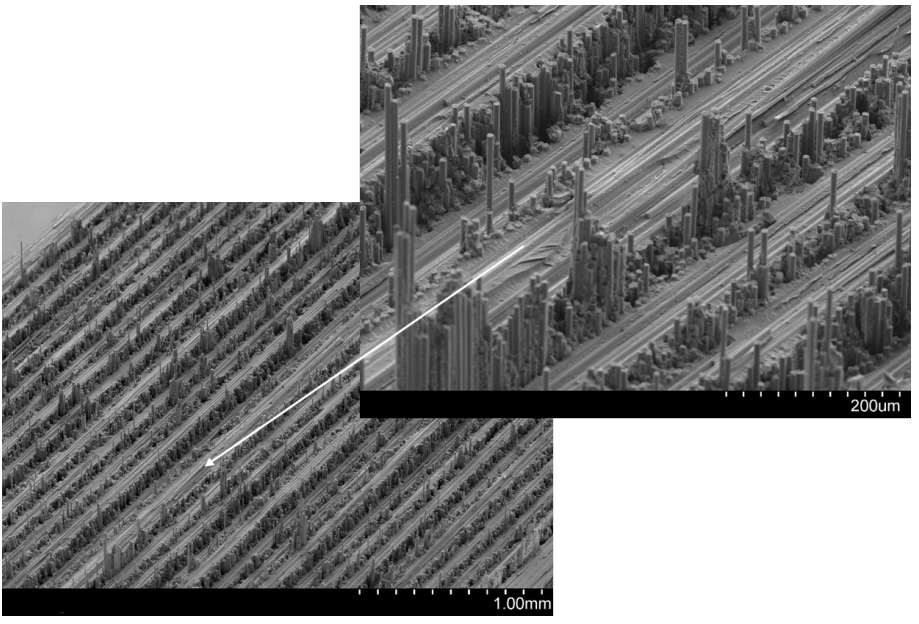

(b) Layup B: $t^{0}=0.055 \mathrm{~mm}$

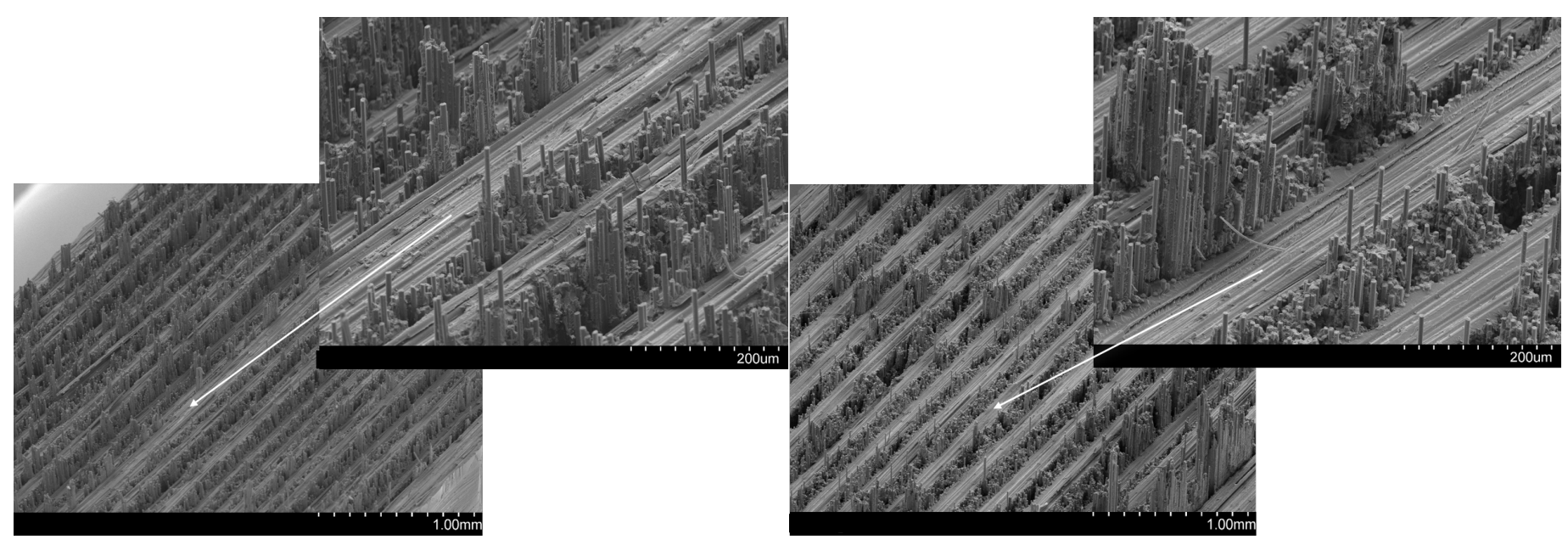

(c) Layup C: $t^{0}=2 \times 0.03=0.06 \mathrm{~mm}$

(d) Layup D: $t^{0}=2 \times 0.055=0.11 \mathrm{~mm}$

Figure 8. SEM fracture surfaces of CP thin-ply laminates showing bundles of fibres pulled out. The pull-out height increases when blocking $0^{\circ}$ plies together. Crack propagates from the bottom left corner to the right top corner. 




(a) Layup A: $t^{0}=0.03 \mathrm{~mm}$

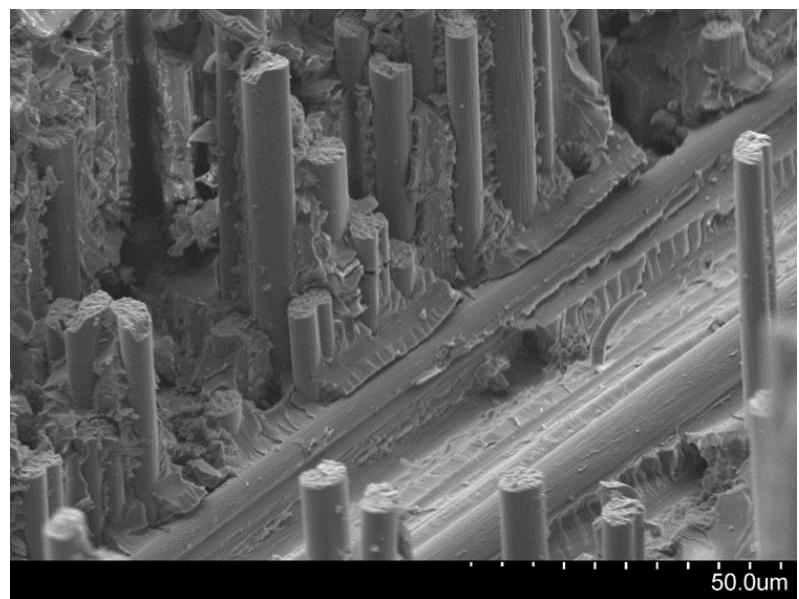

(c) Layup C: $t^{0}=2 \times 0.03=0.06 \mathrm{~mm}$

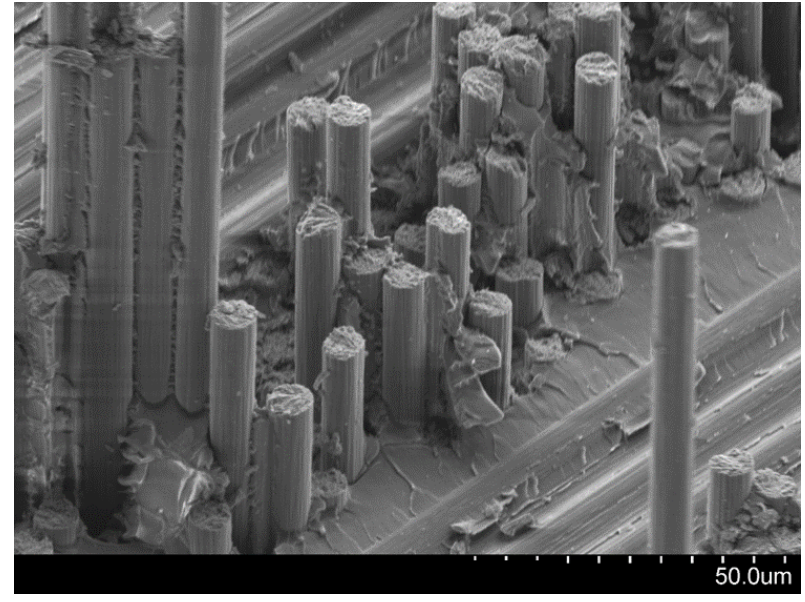

(b) Layup B: $t^{0}=0.055 \mathrm{~mm}$

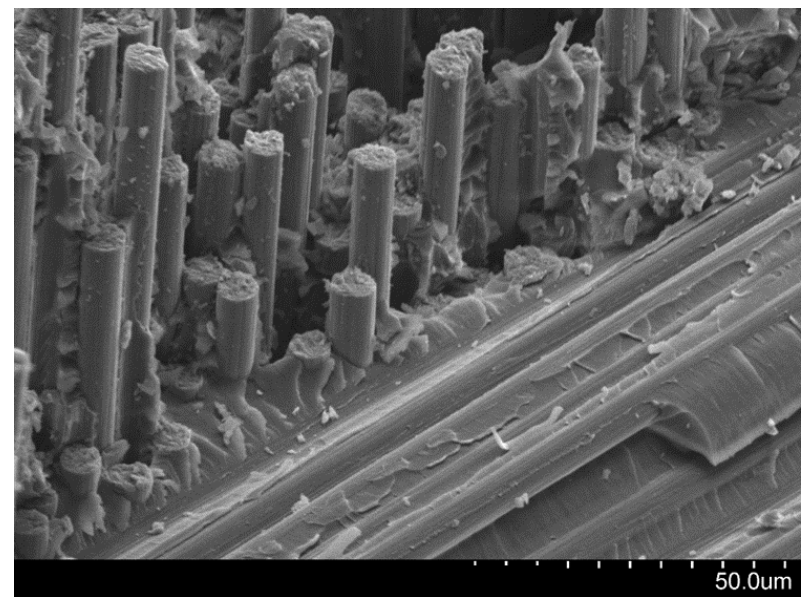

(d) Layup D: $t^{0}=2 \times 0.055=0.11 \mathrm{~mm}$

Figure 9. High magnification SEM fracture surfaces of CP thin-ply laminates. The images were taken in the mid-thickness of the specimens. Crack propagates from the bottom left corner to the right top corner. 


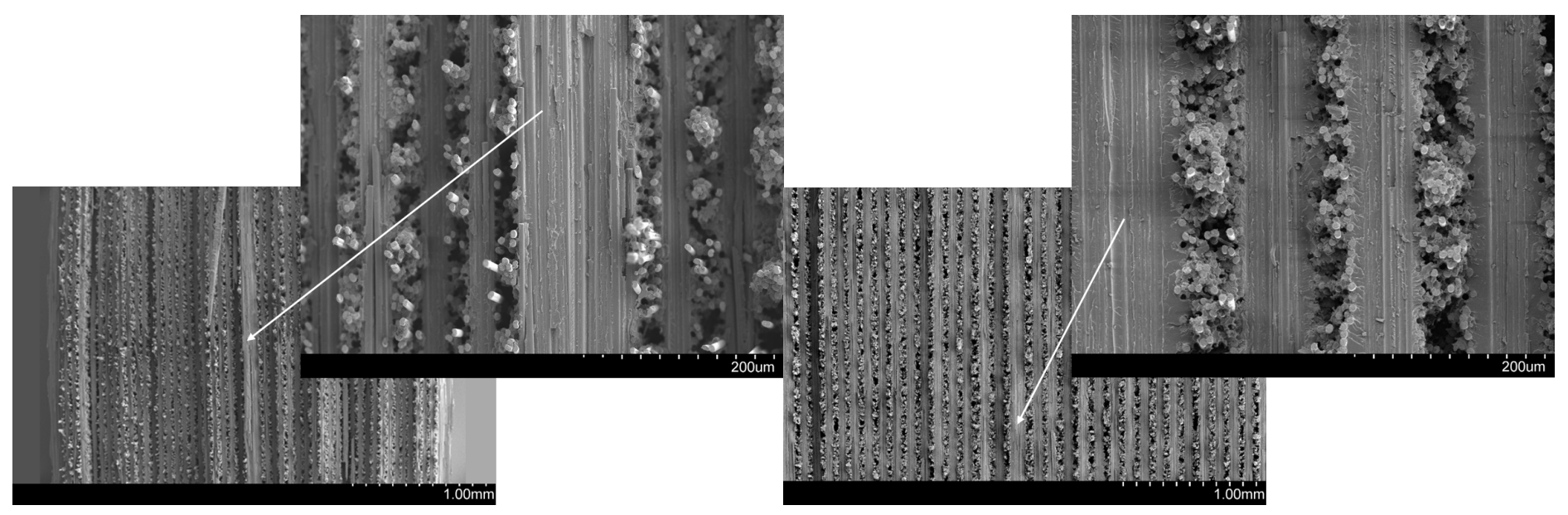

(a) Layup A: $t^{0}=0.03 \mathrm{~mm}$

(b) Layup B: $t^{0}=0.055 \mathrm{~mm}$

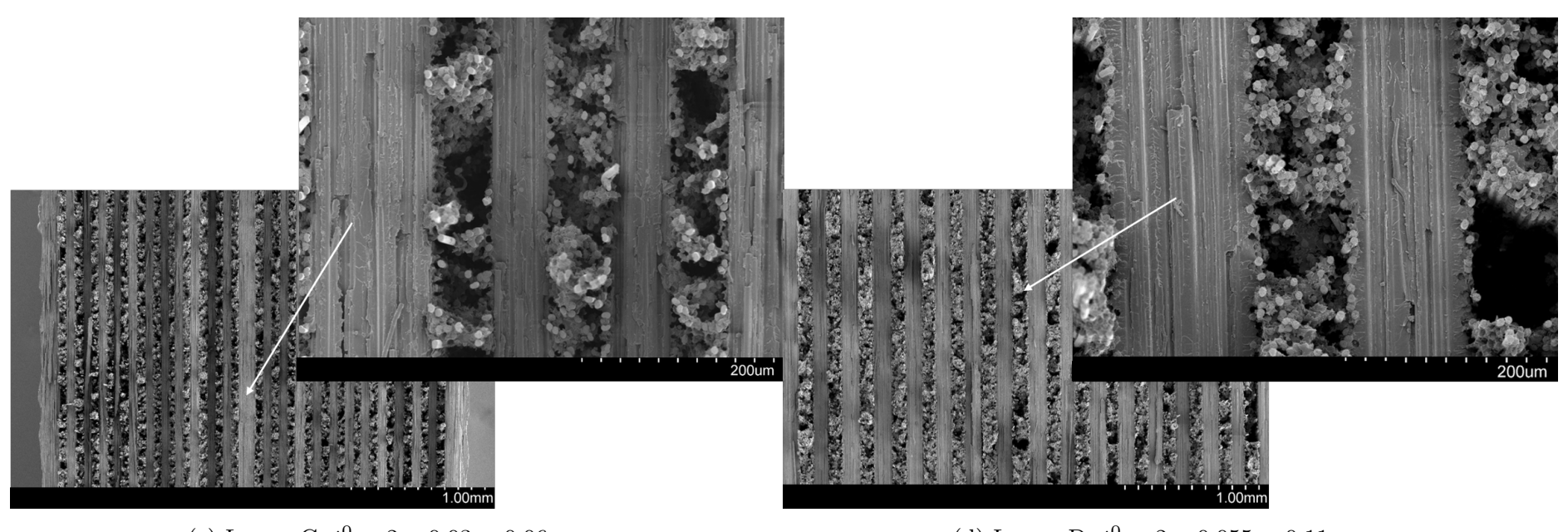

(c) Layup C: $t^{0}=2 \times 0.03=0.06 \mathrm{~mm}$

(d) Layup D: $t^{0}=2 \times 0.055=0.11 \mathrm{~mm}$

Figure 10. Top view of the SEM fracture surfaces of CP thin-ply laminates. in each micrograph, the crack propagates from bottom to top. 


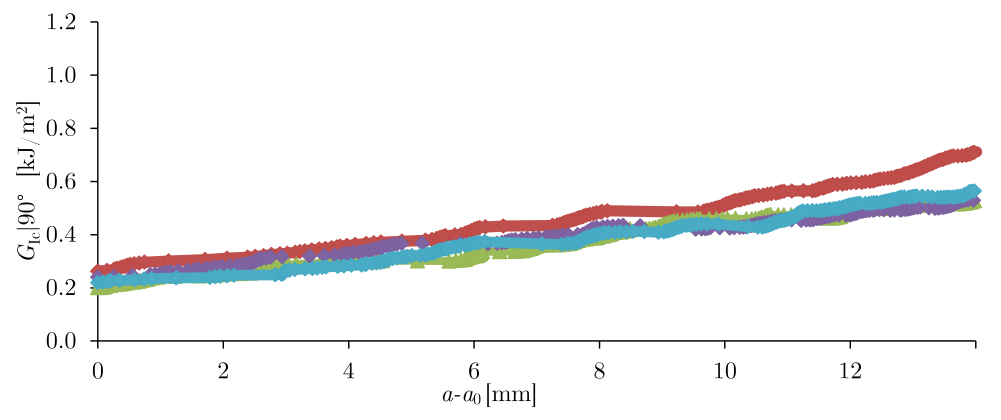

(a) Layup 90

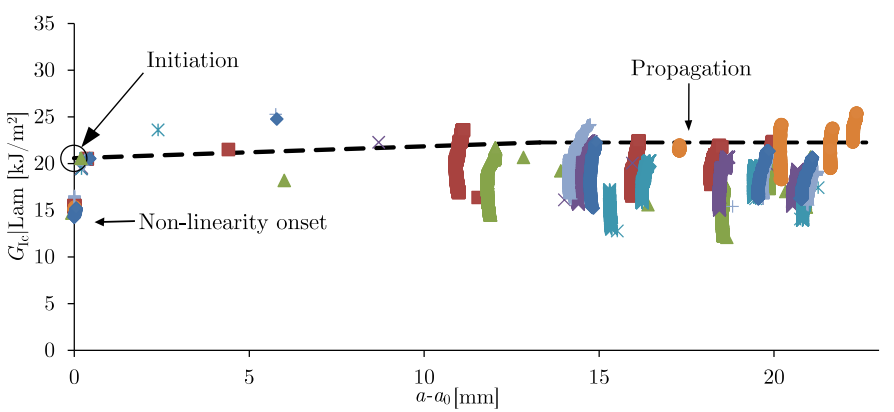

(b) Layup A: $t^{0}=0.03 \mathrm{~mm}$

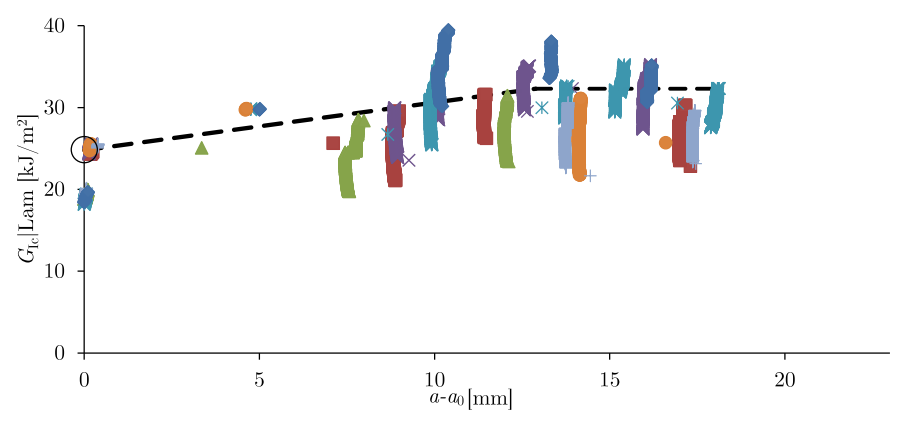

(d) Layup C: $t^{0}=2 \times 0.03=0.06 \mathrm{~mm}$

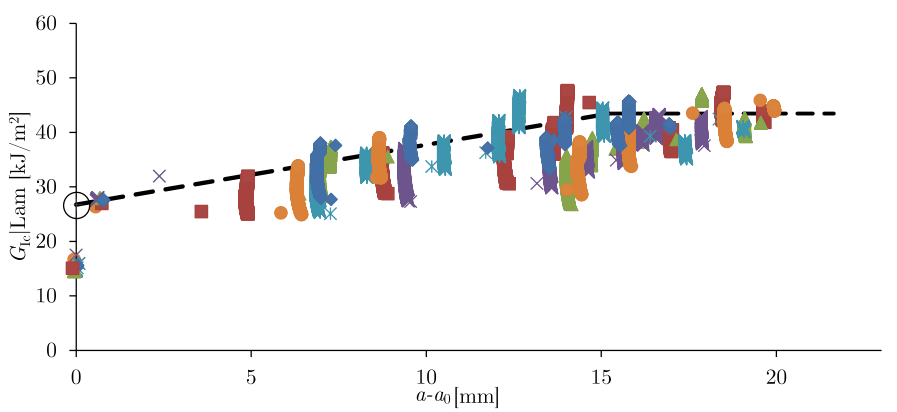

(c) Layup B: $t^{0}=0.055 \mathrm{~mm}$



(e) Layup D: $t^{0}=2 \times 0.055=0.11 \mathrm{~mm}$

Figure 11. $R$-curves for laminate-level translaminar fracture toughness for thin-ply CP laminates (A-D). The intersection between the dashed lines at an angle and the vertical axes defines the initiation toughness and is highlighted with a circle on the vertical axis of each graph. The horizontal dashed lines indicate the propagation toughness. 


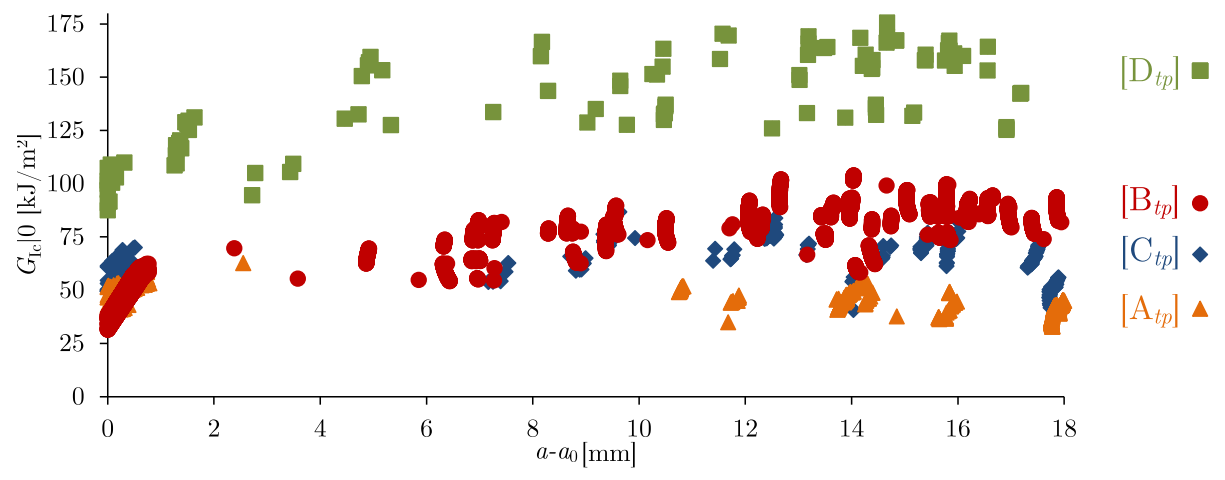

Figure 12. $R$-curves for ply-level translaminar fracture toughness for thin-ply CP laminates (A-D).

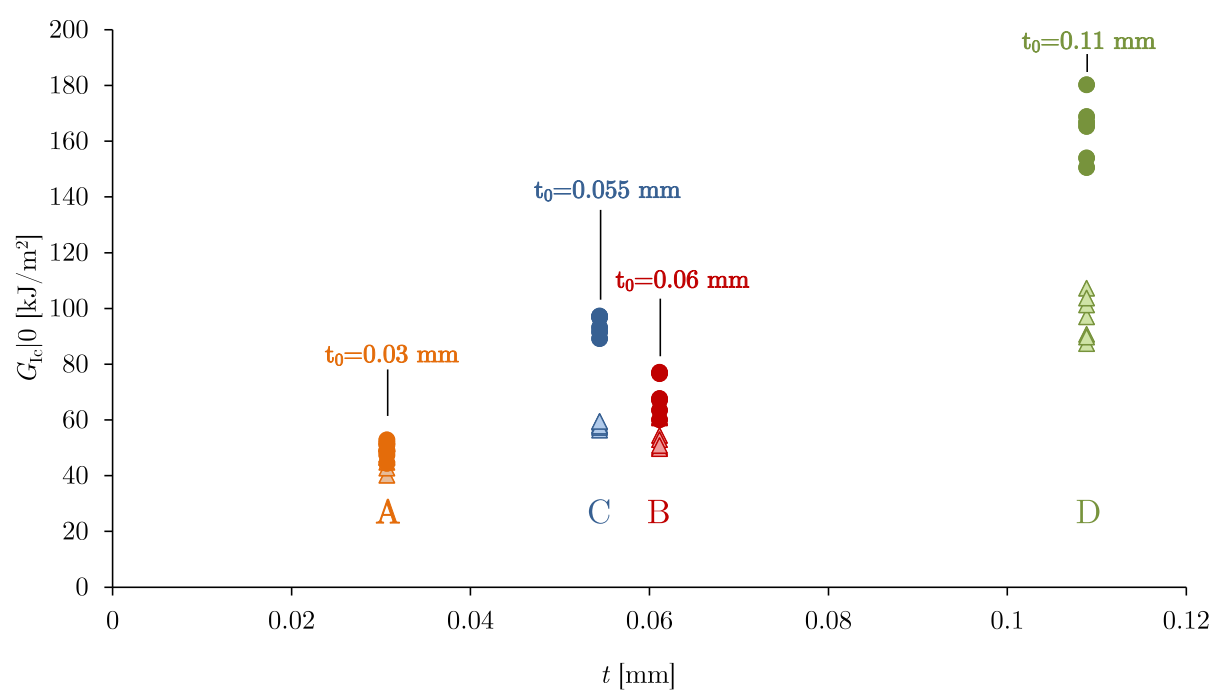

Figure 13. Initiation $(\Delta)$ and propagation $(\bullet)$ toughness values in function of the $0^{\circ}$ ply thickness. 


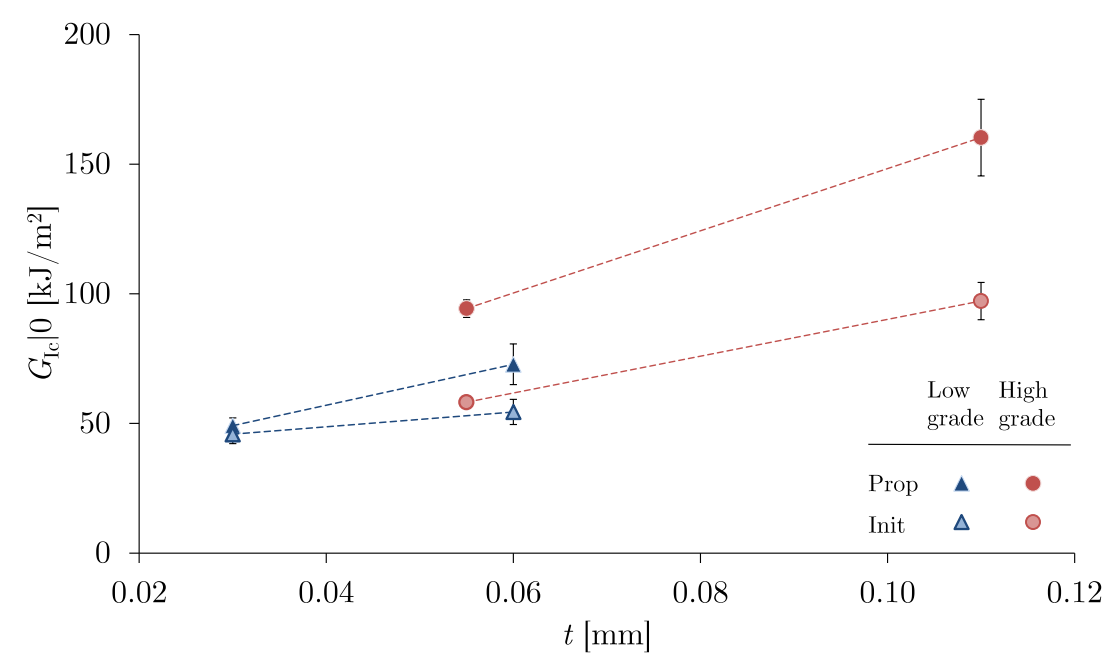

Figure 14. Translaminar fracture toughness increases with $0^{\circ}$ ply-block thickness, with slightly different trendlines for the two grades of the same material tested. 